\title{
Will the Swiss pavilion at Expo 2020 Dubai damage your health?
}

\author{
Nino Künzli ${ }^{1,2,3} \cdot$ Milo A. Puhan ${ }^{1,4} \cdot$ L. Suzanne Suggs ${ }^{1,5}$
}

Received: 25 July 2019/Accepted: 26 July 2019/Published online: 30 July 2019

(C) Swiss School of Public Health (SSPH+) 2019

At the Expo 2020 in Dubai, an emphasis will be on the main purpose of world expositions, namely to further "humanity for the common good through innovation, cultural exchange, creativity and collaboration" (Expo 2020). For the more than 190 participating countries, it offers a unique opportunity to feature their strengths, visions, and successes under the main theme of Expo 2020: "Connecting Minds, Creating the Future." Media just disclosed this month how Switzerland plans to celebrate the future at Expo 2020: Philip Morris International (PMI) shall be one of the two main sponsors of the Swiss pavilion. Taxpayers and private sponsors should equally carry the CHF 15 million budget. The world largest tobacco company has committed to invest 1.8 Mio to be privileged with a permanent exposition space of 75 square meters and the right to use the official Swiss pavilion logo for their own purposes. Now, by the time you read this Editorial, the Swiss Government might have changed its decision. But we have to ask how this could happen at all in the very country where the World Health Organization (WHO) has its headquarters? And when 181 countries have ratified the WHO Framework Convention on Tobacco Control (FCTC) which considers such sponsorship as illegal?

Switzerland belongs to the handful of countries who have not ratified FCTC. Though the Federal Council has the ratification on its agenda, the priority to adopt it seems rather low. Expo 2020 is just another example of the longstanding intimate ties between the tobacco industry and the Swiss government and its policy-making arena. Until the

Nino Künzli

nkuenzli@ssphplus.ch

1 Swiss School of Public Health (SSPH+), Hirschengraben 82, 8001 Zurich, Switzerland

2 Swiss Tropical and Public Health Institute (Swiss TPH), Basel, Switzerland

3 University of Basel, Basel, Switzerland

4 Epidemiology, Biostatistics and Prevention Institute, University of Zurich, Zurich, Switzerland

5 Università della Svizzera Italiana, Lugano, Switzerland turn of the century, the tobacco industry was an official member of the governmental advisory board on tobacco policy-making. The three world-leading tobacco manufacturers-PMI, British American Tobacco (BAT), and Japan Tobacco International-have their global headquarters in Switzerland. Their lobbying is the underlying cause for the inability of Swiss policy-makers to line up laws with the FCTC. The approval of the PMI sponsorship at Expo 2020 reflects this tobacco-friendly policy environment (Burnand 2018).

For decades, smoking continues to be the second-leading cause of premature diseases and deaths (GBD 2017 Risk Factor Collaborators 2018). The smoking-driven epidemic of non-communicable diseases is particularly deleterious in poorer countries where lack of health insurance and limited health system resources are prevailing. People suffering from tobacco-related diseases in those countries are an enormous burden on the household economies of entire families. How will low- and middleincome country officials perceive the Swiss pavilion given the strategy of PMI and its allies to aggressively promote cigarettes in Africa and Asia? In Africa alone, sales of cigarettes increased by 44\% from 1990 to 2012 (Vellios et al. 2017). How can the pavilion of one of the wealthiest countries in the world accept a sponsor who promotes cigarettes particularly among the poor (Lampert and Glantz 2019)?

The Swiss pavilion would offer PMI a timely marketing platform for their newest business pillar (PMI 2019): The next generation of nicotine addicts shall depend on smokeless gadgets, marketed in fashionable designs and flavors, tailored to the lifestyles of the youngest generation. Yes, there is hope that these new tools may be less harmful than cigarettes. Though the online propaganda of PMI currently focuses on harm reduction in smokers (PMI 2019), the added value of smokeless nicotine devices as compared to traditional nicotine replacement and smoking cessation methods is far from proven (Khoudigian et al. 2016). Indeed, claims of PMI to target only smokers with those new nicotine gadgets are disproven by their Expo 2020 investment: The vast majority of Expo 2020 visitors 
will be non-smokers and many will be young (GBD Tobacco Collaborators 2017). Young non-smokers are prime marketing targets of the e-gadgets, and evidence continues to emerge showing an increasing number of adolescent non-smokers opt for smokeless tools, although long-term health effects are not yet established (Dinakar and O'Connor 2016; Glantz and Bareham 2018). The list of substances inhaled by the consumers of these new products is long (Zhao et al. 2018). Does it matter that formaldehyde, a Group 1 carcinogen, can reach several-fold higher concentrations in smokeless e-tools as compared to traditional cigarettes (Jensen et al. 2015)? What is the relevance of a recent report showing that PMI's novel gadget impairs human airway cell homeostasis (Sohal et al. 2019) or of the cellular response of e-vapor observed in an ongoing Swiss research project (Delaval et al. 2018)? How would PMI explain such facts and open questions to the Expo 2020 visitors?

We conclude that featuring the world-leading producer of cigarettes - the only product known to kill half of its consumers-at Expo 2020 remains unethical no matter what the long-term nicotine business model of PMI may look like-tobacco companies do not serve public health (Fairchild et al. 2019). Harsh criticism of WHO and the enormous media outcry in mid-July fully aligned with the public health perspective. Hopefully, the Government of the United Arab Emirates (UAE), who signed the FCTC, will express their irritation about the attempt to discredit FCTC on UAE territory. The Swiss School of Public Health-owner of this Journal-and a wide range of national constituencies are actively working to get the Swiss government to rescind this sponsorship. Thus, by the time you read this Editorial, the Swiss government might have stopped this scandal. In that regard, this Editorial sends a huge "Thank you!" to the leading Councilor-who is a physician and public health expert. To all those who approve that PMI will have any sponsorship or appearance at Expo 2020, this Editorial sends a "shame on you"!

To all readers of this Editorial, what are you doing to make sure the Expo 2020 pavilion of your country will not damage your health? Watch out—one never knows!

\section{References}

Burnand F (2018) SWI Swissinfo.ch, https://www.swissinfo.ch/eng/ lobbying_switzerland-the-land-of-the-tobacco-industry/ 44449446. Accessed 21 July 2019
Delaval M, Egli D, Jonsdottir HR, Schuepfer P, Baumlin N, Salathe ME, Burtscher H, Geiser M (2018) Evaluating adverse effects of aerosols from different electronic cigarettes to airway epithelia by realistic in vitro technologies. Am J Respir Crit Care Med 197:A3562

Dinakar C, O'Connor GT (2016) The health effects of electronic cigarettes. N Engl J Med 375:1372-1381

Expo 2020, Dubai, United Arab Emirates. Official website. https:// www.expo2020dubai.com/en/discover/about. Accessed 21 July 2019

Fairchild AL, Bayer R, Sung Lee J (2019) The E-cigarette debate: what counts as evidence? Am J Public Health 109:1000-1006. https://doi.org/10.2105/AJPH.2019.305107

GBD 2015 Tobacco Collaborators (2017) Smoking prevalence and attributable disease burden in 195 countries and territories, 1990-2015: a systematic analysis from the Global Burden of Disease Study 2015. Lancet 389(10082):1885-1906

GBD 2017 Risk Factor Collaborators (2017) Global, regional, and national comparative risk assessment of 84 behavioural, environmental and occupational, and metabolic risks or clusters of risks for 195 countries and territories, 1990-2017: a systematic analysis for the Global Burden of Disease Study 2017. Lancet 392:1923-1994

Glantz SA, Bareham DW (2018) E-cigarettes: use, effects on smoking, risks, and policy implications. Annu Rev Public Health 39:215-235

Jensen RP, Luo W, Pankow JF, Strongin RM, Peyton DH (2015) Hidden Formaldehyde in E-cigarette aerosols (letter to the editor). N Engl J Med 372:392-394

Khoudigian S, Devji T, Lytvyn L et al (2016) The efficacy and shortterm effects of electronic cigarettes as a method for smoking cessation: a systematic review and a meta-analysis. Int J Public Health 61(2):257-267

Lampert KL, Glantz SA (2019) Tobacco industry promotional strategies targeting American Indians/alaska natives and exploiting tribal sovereignty. Nicotine Tob Res 21(7):940-948

Philip Morris International (2019) Designing a smoke free future. https://www.pmi.com/. Accessed 21 July 2019

Sohal SS, Eapen MS, Naidu VGM et al (2019) IQOS exposure impairs human airway cell homeostasis: direct comparison with traditional cigarette and e-cigarette. ERJ Open Res 5:00159-02018. https://doi.org/10.1183/23120541.00159-2018

Vellios N, Ross H, Perucic AM (2017) Trends in cigarette demand and supply in Africa. PLoSONE 13(8):e0202467. https://doi.org/ 10.1371/journal.pone.020246

Zhao J, Nelson J, Dada O, Pyrgiotakis G, Kavouras IG, Demokritou P (2018) Assessing electronic cigarette emissions: linking physicochemical properties to product brand, e-liquid flavoring additives, operational voltage and user puffing patterns. Inhal Toxicol 30:78-88. https://doi.org/10.1080/08958378.2018. 1450462

Publisher's Note Springer Nature remains neutral with regard to jurisdictional claims in published maps and institutional affiliations. 